Brit. J. vener. Dis. (1957), 33, 40.

\title{
BENZATHINE PENICILLIN G IN THE CONTROL OF GONORRHOEA*
}

\author{
BY \\ CARL E. HOOKINGS $\ddagger$ AND L. M. GRAVES $\S$ \\ From the Division of Venereal Disease Control, Memphis, and from the Shelby County Health Department, \\ Memphis, Tennessee
}

Since the introduction of penicillin in the therapy of venereal disease by Mahoney, Arnold, and Harris (1943), a form of the drug has been sought which will cure both syphilis and gonorrhoea in a single dose. This has led to the introduction of various forms of penicillin beginning with the amorphous type, which had to be injected every 2 or 3 hours. This was followed by the Romansky formula of penicillin $G$ in peanut oil and beeswax (POB) (Romansky and Rittman, 1944), then by procaine penicillin $G$ with aluminium monostearate (PAM) with a therapeutic life of about 72 hours, and finally by dibenzylethylenediamine dipenicillin $G$ (benzathine penicillin $G \dagger$ ) which, in a single dose of 600,000 units, Welch, Randall, and Hendricks (1953) found to have a therapeutic life of some 16 days. All these forms of penicillin have been found to be curative in cases of syphilis and gonorrhoea, but in spite of this the incidence of gonorrhoea has not been greatly reduced.

In searching for a reason for this failure to control the disease, it was found that, in spite of almost immediate cure in cases of male gonorrhoea, the dose and variety of penicillin employed, which has almost universally been 600,000 units penicillin $\mathrm{G}$ with 2 per cent. aluminium monostearate (PAM), failed to cure female gonorrhoea. This was reflected in the fact that 15 per cent. of women were again named as contacts in the 60 days following their initial visit to the public health venereal disease clinic, Eve Hall, Memphis, during the period from January to July, 1955.

\footnotetext{
* Received for publication December 31, 1956.

+ Supplied by Research Division, Wyeth Laboratories, under brand name of Bicillin.

¥ Director, Division of Venereal Disease Control, Memphis, Tenn. $\S$ Director, Memphis and Shelby County Health Department, Memphis, Tenn.
}

On March 16, 1953, the system known as "speed zone" epidemiology, in which male cases of venereal disease were interviewed for relevant contacts, was introduced in the Memphis and Shelby County Health Department. These contacts were investigated immediately with the object of bringing them to examination and treatment within 72 hours of their being named. This procedure worked satisfactorily, 80 per cent. or more of the contacts being brought to examination and treatment within the prescribed period, and actually more than 75 per cent. being brought within 24 hours after being named. In spite of this, the number of males attending the clinic and diagnosed as having gonorrhoea remained essentially the same during the years 1953 , 1954, and 1955.

It became apparent that some form of therapy would have to be introduced which would render the male incapable of being re-infected until the disease in his female contacts was cured; the time factor seemed much more important than the size of the initial dose of penicillin. With this in mind, on January 1, 1956, we began to treat the females with PAM 600,000 units plus $1 \cdot 2$ million units benzathine penicillin $G$. At the same time the records of all female contacts were tagged so that any repeat visit to the clinic would be readily recognized. By the end of 60 days, the repeat rate, which had been 15 per cent. in 1955, had dropped to 1.7 per cent. A decline was seen in the weekly male attendances at the clinic when the figures for the 2-year period 1954 and 1955 were compared with those for 1956 (Table).

On April 1, 1956, males as well as females began to receive 600,000 units PAM plus $1 \cdot 2$ million units benzathine penicillin $G$, and since then there has been an increasingly marked decline in the attendance of males at the clinic. 
TABLE

GONORRHOEA CASES IN MALES (MEMPHIS AND SHELBY COUNTY HEALTH DEPARTMENT)

\begin{tabular}{|c|c|c|c|c|c|}
\hline \multirow{2}{*}{\multicolumn{2}{|c|}{ Month }} & \multirow{2}{*}{ Week } & \multicolumn{3}{|c|}{ Year } \\
\hline & & & 1954 & 1955 & $1956^{*}$ \\
\hline January & . & $\begin{array}{l}1 \\
2 \\
3 \\
4\end{array}$ & $\begin{array}{l}66 \\
53 \\
56 \\
55\end{array}$ & $\begin{array}{l}83 \\
59 \\
77 \\
76\end{array}$ & $\begin{array}{l}47 \\
53 \\
56 \\
59\end{array}$ \\
\hline February & . & $\begin{array}{l}1 \\
2 \\
3 \\
4\end{array}$ & $\begin{array}{l}63 \\
60 \\
47 \\
57\end{array}$ & $\begin{array}{l}58 \\
55 \\
53 \\
58\end{array}$ & $\begin{array}{l}58 \\
55 \\
49 \\
48\end{array}$ \\
\hline March & . & $\begin{array}{l}1 \\
2 \\
3 \\
4 \\
5\end{array}$ & $\begin{array}{l}53 \\
49 \\
56 \\
47 \\
60\end{array}$ & $\begin{array}{l}48 \\
71 \\
59 \\
50 \\
75\end{array}$ & $\begin{array}{r}45 \\
54 \\
57 \\
38 \\
.62\end{array}$ \\
\hline April & . & $\begin{array}{l}1 \\
2 \\
3 \\
4\end{array}$ & $\begin{array}{l}48 \\
56 \\
61 \\
58\end{array}$ & $\begin{array}{l}41 \\
53 \\
49 \\
59\end{array}$ & $\begin{array}{l}54 \dagger \\
43 \\
42 \\
54\end{array}$ \\
\hline May.. & . & $\begin{array}{l}1 \\
2 \\
3 \\
4\end{array}$ & $\begin{array}{l}59 \\
61 \\
82 \\
72\end{array}$ & $\begin{array}{l}74 \\
54 \\
64 \\
54\end{array}$ & $\begin{array}{l}49 \\
52 \\
50 \\
58\end{array}$ \\
\hline \multicolumn{3}{|c|}{ 5-Month Total } & 1219 & 1270 & 1083 \\
\hline June. . & . & $\begin{array}{l}1 \\
2 \\
3 \\
4 \\
5\end{array}$ & $\begin{array}{l}73 \\
62 \\
70 \\
78 \\
65\end{array}$ & $\begin{array}{l}80 \\
54 \\
74 \\
74 \\
88\end{array}$ & $\begin{array}{l}51 \\
55 \\
59 \\
52 \\
63\end{array}$ \\
\hline July & . & $\begin{array}{l}1 \\
2 \\
3 \\
4\end{array}$ & $\begin{array}{l}66 \\
66 \\
76 \\
67\end{array}$ & $\begin{array}{l}56 \\
73 \\
73 \\
68\end{array}$ & $\begin{array}{l}43 \\
51 \\
65 \\
52\end{array}$ \\
\hline August & . & $\begin{array}{l}1 \\
2 \\
3 \\
4\end{array}$ & $\begin{array}{l}78 \\
80 \\
90 \\
71\end{array}$ & $\begin{array}{l}73 \\
89 \\
90 \\
87\end{array}$ & $\begin{array}{l}51 \\
69 \\
64 \\
45\end{array}$ \\
\hline September & . & $\begin{array}{l}1 \\
2 \\
3 \\
4 \\
5\end{array}$ & $\begin{array}{l}83 \\
50 \\
62 \\
63 \\
71\end{array}$ & $\begin{array}{l}90 \\
72 \\
65 \\
74 \\
76\end{array}$ & $\begin{array}{l}70 \\
54 \\
47 \\
38 \\
44\end{array}$ \\
\hline October & . & $\begin{array}{l}1 \\
2 \\
3 \\
4\end{array}$ & $\begin{array}{l}61 \\
76 \\
55 \\
48\end{array}$ & $\begin{array}{l}46 \\
56 \\
55 \\
60\end{array}$ & $\begin{array}{l}38 \\
38 \\
53 \\
54\end{array}$ \\
\hline November & . & $\begin{array}{l}1 \\
2 \\
3 \\
4\end{array}$ & $\begin{array}{l}59 \\
56 \\
48 \\
55\end{array}$ & $\begin{array}{l}50 \\
33 \\
63 \\
41\end{array}$ & $\begin{array}{l}33 \\
34 \\
55 \\
36\end{array}$ \\
\hline December & . & $\begin{array}{l}1 \\
2 \\
3 \\
4 \\
5\end{array}$ & $\begin{array}{l}57 \\
56 \\
51 \\
41 \\
56\end{array}$ & $\begin{array}{l}53 \\
55 \\
47 \\
34 \\
62\end{array}$ & \\
\hline
\end{tabular}

* Beginning January 1, 1956, females were treated with 600,000 units PAM and 1.2 million units Benzathine Penicillin G.

+ Beginning April 1, 1956, males were treated with 600,000 units PAM and 1.2 million units Benzathine Penicillin G.

Was this decline more apparent than real? Were any other factors at work, such as a marked decrease in the Negro population (for 99 per cent. of the cases attending the clinic were Negroes), or were physicians attending more gonorrhoea cases in their surgeries than formerly? The estimated Negro population of
Memphis and Shelby County showed a steady rise as follows: 1954, 190,763; 1955, 193,252; 1956, 195,741. The actual population registered in coloured schools in the county was: $1954,40,695$; $1955,43,419 ; 1956,46,258$. The reporting of gonorrhoea cases by physicians is most unreliable, but we have no reason to believe, after personally questioning a sample of the physicians, that there has been any increase in the number of cases being so treated.

When we applied statistical analysis to the attendance figures at our clinic, going back as far as we had accurate data, we saw no decline at all in the attendance of male patients with diagnosed gonorrhoea. In applying the $\chi^{2}$ test, it seemed justifiable to take the number of cases which had actually attended in each 4-week period (lunar month) in 1955 as our expected number of cases in the corresponding period of 1956 (Fig. 1).

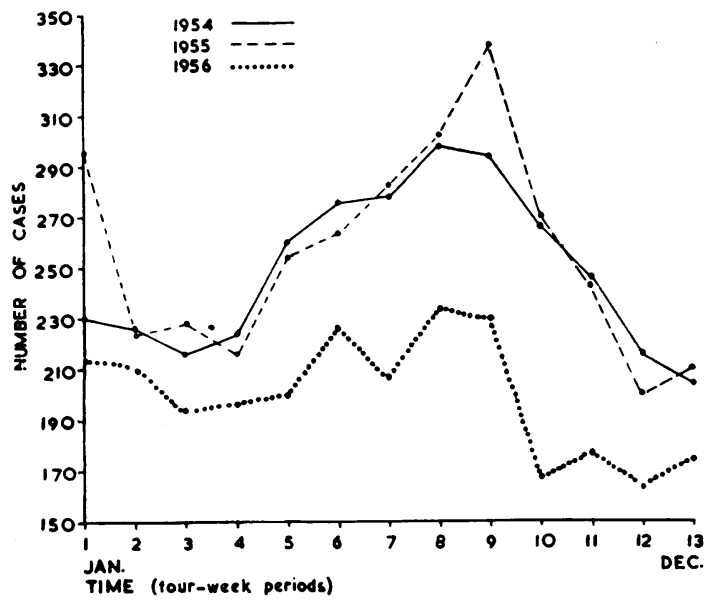

Fig. 1.-Number of cases of male gonorrhoea for the years 1954, 1955, and 1956 , by 4 -week periods.

Calculations made on this basis show that there was a $\chi^{2}$ of 80 plus, using five degrees of freedom. The $\chi^{2}$ table showing significant changes compared with $\chi^{2} 80$ plus was computed for the last 3 months, June, July, and August. A graph drawn on arithmetical graph paper, and giving the attendances based on 4-week periods during 1954, 1955, and 1956, shows that in 1954 and 1955 there was a very marked rise in male cases of gonorrhoea in the clinic from the 4th to the 9th period and then a sharp decline. By comparison with this, the arithmetical curve of 1956 starts at a lower level in January, but is parallel to the 1954 and 1955 curves for the first four periods. At this time benzathine penicillin $G$ was introduced in the treatment of both males and 
females and from this date the curve fails to reach that for 1954 and 1955, although a small seasonal rise is again noticed at the end of the year (Fig. 2).

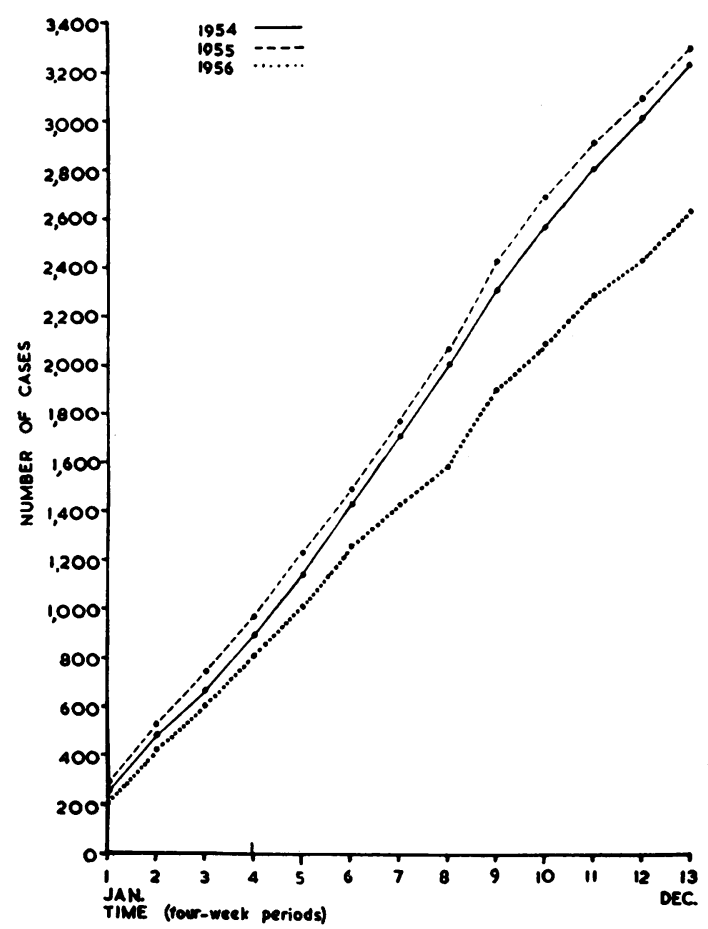

Fig. 2.-Cumulative graph (number of male cases of gonorrhoea).

In transferring this curve to semi-log paper, the divergence between the 1955 and 1956 graphs becomes more apparent (Fig. 3).

Stollerman and Rusoff (1952) have shown that, in ten patients, $1 \cdot 2$ million units benzathine penicillin $G$ in a single injection gave a continuous average serum concentration of 0.04 units $/ \mathrm{ml}$. or more, for a period of 35 days, using the Sarcina lutea method of estimation of penicillin. A blood level of this magnitude should perhaps render a male immune to re-infection with the gonococcus for a period of 28 days at least, and should give the female a chance to overcome her infection however deeply seated in the paravaginal and cervical glands it might be.

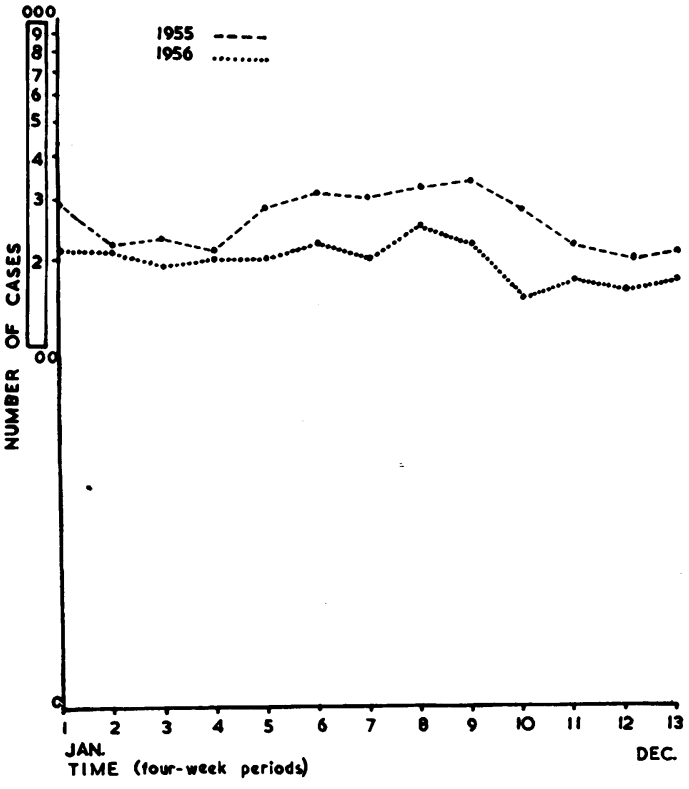

Fig. 3.-Semi-log graph showing number of male cases of gonorrhoea.

We feel that our clinical results have justified this conclusion and that a regimen of 600,000 units PAM plus $1 \cdot 2$ million units benzathine penicillin $G$ should be adopted as the treatment of choice in this disease. Although such a regimen would cure the disease in male and female, we think that in order to control the disease in a population, it is also necessary to adopt the "speed zone" epidemiological investigation. Unless the females are quickly brought to examination and treatment, they will continue to spread the disease in the male population and hence render any purely curative measures worthless as a means of control, for there will always be in the population a core of infection unknown to the controlling agency.

\section{REFERENCES}

Mahoney, J. F., Arnold, R. C., and Harris, A. (1943). Vener. Dis. Inform., 24, 355

Romansky, M. J., and Rittman, G. E. (1944). Bull. U.S. Army med. Dep., 2, no. 81, p. 43.

Welch, H., Randall, W. A., and Hendricks, F. D. (1953). Antibiot. and Chemother., 3 , 1053

Stollerman, G. H., and Rusoff, J. H. (1952). J. Amer. med. Ass., 150, 1571 . 